\title{
Seasonal production of photosynthetic picoplankton and nanoplankton in the Celtic Sea
}

\author{
I. R. Joint, N. J. P. Owens \& A. J. Pomroy \\ Natural Environment Research Council, Institute for Marine Environmental Research, Prospect Place, The Hoe, \\ Plymouth PL13DH, United Kingdom
}

\begin{abstract}
Primary production by picoplankton and other phytoplankton has been measured in all seasons in the Celtic Sea. Picoplankton production was greatest during the summer but was always less than that of small nanoplankton which accounted for most of the primary production throughout the year. Large phytoplankton ( $>5 \mu \mathrm{m}$ ) was quantitatively the most important only for a short period of the spring diatom bloom. In winter, small nanoplankton $(<5$ to $>1 \mu \mathrm{m})$ accounted for almost $70 \%$ and picoplankton for $13 \%$ of the daily primary production. Annual phytoplankton production was $102 \mathrm{~g} \mathrm{C}$ $\mathrm{m}^{-2} \mathrm{yr}^{-1}$ (excluding production of dissolved arganic carbon, which was about 10 to $15 \%$ of the particulate production). Phytoplankton $>5 \mu \mathrm{m}$ fixed $37.89 \mathrm{~g} \mathrm{C} \mathrm{m}^{-2} \mathrm{yr}^{-1}$ but half of this production occurred during the spring diatom bloom in April. Small nanoplankton $(<5$ to $>1 \mu \mathrm{m})$ fixed $41.86 \mathrm{gC}$ $\mathrm{m}^{-2} \mathrm{yr}^{-1}$ and picoplankton $(<1 \mu \mathrm{m})$ fixed $23.06 \mathrm{~g} \mathrm{C} \mathrm{m}^{-2} \mathrm{yr}^{-1}$
\end{abstract}

\section{INTRODUCTION}

Since the first reports of very small unicellular cyanobacteria in the sea (Johnson \& Sieburth 1979, Waterbury et al. 1979) there have been many reports which have shown the quantitative importance of small phytoplankton cells in various marine provinces, from the polar seas to the tropics (Gieskes et al. 1979, Krempin \& Sullivan 1981, Joint \& Pomroy 1983, Li et al. 1983, Platt et al. 1983, Takahashi \& Bienfang 1983, Bienfang et al. 1984, Douglas 1984, Takahashi \& Hori 1984, Murphy \& Haugen 1985, Smith et al. 1985). These small cells have come to be known as picoplankton, which was defined by Sieburth et al. (1978) as microbes between $0.2 \mu \mathrm{m}$ and $2 \mu \mathrm{m}$.

It is now known that photosynthetic picoplankton is composed of both cyanobacteria and very small eukaryotic algae, which are of the same size as bacteria. Studies with the transmission electron microscope have demonstrated cyanobacteria, with their characteristic thylakoids arranged around the periphery of the cell, and small eukaryotic algae, which usually have a single chloroplast. Both types of organism have been found in the western North Atlantic by Johnson \& Sieburth (1982), the western North Pacific and South China Sea (Takahashi \& Hori 1984) and on the European continental shelf in the Celtic Sea by Joint \& Pipe (1984). Little is known about the factors controlling picoplankton distribution but recently Murphy \& Haugen (1985) suggested that there is a relationship between abundance of cyanobacteria and latitude, since cyanobacterial numbers declined with northerly increasing latitude and with decreasing temperature.

The contribution picoplankton makes to primary production varies and has been reported to be as high as $80 \%$ of the daily carbon fixation for the tropical Pacific Ocean (Li et al. 1983) and up to $60 \%$ for the subtropical Atlantic (Platt et al. 1983). The importance of picoplankton production appears to be less in temperate waters; Joint \& Pomroy (1983) found that picoplankton accounted for 20 to $30 \%$ of the primary production in the Celtic Sea in summer and Douglas (1984) reported values of 12.7 to $29.7 \%$ for the continental shelf off Nova Scotia.

However, it is still not clear what is the seasonal significance of picoplankton production, particularly in temperate waters which experience significant seasonal variations in insolation and temperature. Inevitably, most studies have been restricted to relatively short periods of time, usually constrained by the length of a cruise, and there are no estimates of the seasonal significance of primary production by this small phytoplankton. Our previous work in the Celtic Sea (Joint \& Pomroy 1983) demonstrated that picoplankton could account for up to $30 \%$ of the summer primary produc- 
tion but we had very little information about production rates at other times of the year. The purpose of this paper is to report the results of measurements of sizefractionated primary production made, in all seasons, over a 2 yr period in the Celtic Sea and to use these data to estimate the annual contribution of picoplankton and nanoplankton to the Celtic Sea ecosystem.

\section{METHODS}

Measurements were made at several stations in the Celtic Sea (Fig. 1); in addition to Stn CS2, which was studied by Joint \& Pomroy (1983), several other stations were sampled on the continental shelf and on the shelf șlope. Sampling and experimental methods were the

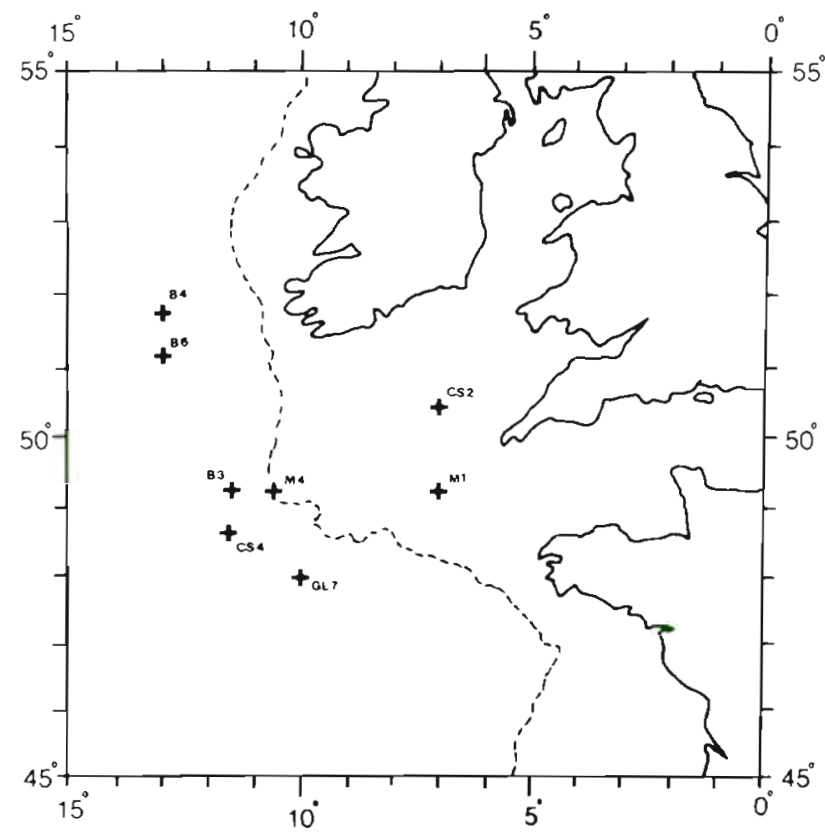

Fig. 1. The Celtic Sea showing the positions of the stations sampled; dashed line indicates the $200 \mathrm{~m}$ contour

same as used by Joint \& Pomroy (1983) and our approach has been to do post-incubation size fractionation so that interactions occurring in the microbial community are disrupted as little as possible. Briefly, primary production was measured using the ${ }^{14} \mathrm{C}$ method. ${ }^{14} \mathrm{C}$ solutions were purified before use by the method of Wiebe \& Smith (1977); water samples were incubated in $60 \mathrm{ml}$ disposable plastic tissue-culture bottles with 1 to $10 \mu \mathrm{Ci} \mathrm{Na}_{2}{ }^{14} \mathrm{CO}_{3}$. Incubations were done in situ for $24 \mathrm{~h}$ by suspending the samples at the 9 depths from which they were taken; water samples were collected at dawn and care was taken not to expose deep samples to bright light. At each depth, 3 samples were incubated in clear tissue-culture bottles and one addi- tional sample was incubated in a bottle wrapped in aluminium foil and black masking tape, to give an estimate of dark $\mathrm{CO}_{2}$ fixation. The bottles were held in clear acrylic bottle holders, fixed to a wire and suspended from a light toroid buoy which was constructed to give minimum shading of the samples. The string of incubation bottles was left free-floating well away from the ship during incubations.

At the end of the incubation period, the bottles were retrieved and kept in the dark until filtered. The samples were size fractionated by passing through a cascade of 3 different $47 \mathrm{~mm}$ diameter Nuclepore ${ }^{\circledR i}$ filters; pore sizes used were usually 5,1 and $0.2 \mu \mathrm{m}$, although for some experiments done in summer 1983, 0.8um pore filters replaced the $1 \mu \mathrm{m}$ pore-size. Samples were filtered through the $5 \mu \mathrm{m}$ filters by gravity only and no vacuum was applied; small pressure differences were required for the other filters but were never greater than $5 \mathrm{~cm} \mathrm{Hg}$ for the $1 \mu \mathrm{m}$ or $15 \mathrm{~cm} \mathrm{Hg}$ for the $0.2 \mu \mathrm{m}$ filter. The filters were placed in scintillation vials and transferred to a desiccator with active silica gel. The filters dried quickly $(<1 \mathrm{~h})$ by this method and were kept desiccated until returned to the laboratory; toluene-based scintillation cocktail was added to the vials and the samples were counted in a liquid scintillation counter, counting efficiency being determined by the external-standard channels-ratio method and by occasional addition of an internal standard. The amount of ${ }^{14} \mathrm{C}$ added to each experimental bottle at sea was checked by sampling aliquots of the ${ }^{14} \mathrm{C}$ solution into a $\mathrm{CO}_{2}$-absorbing scintillation cocktail and these samples were also counted on return to the laboratory. Production of ${ }^{14} \mathrm{C}$-labelled dissolved organic carbon $\left(D^{14} \mathrm{C}\right)$ was assessed in the filtrate from the experimental bottles, which was acidified to about $\mathrm{pH} 2$ with sulphuric acid. On return to the laboratory, three $10 \mathrm{ml}$ aliquots were removed from each sample, bubbled with air for 1 h using the apparatus of Wessels \& Birnbaum (1979) and mixed with an equal volume of Aquasol ${ }^{\circledR}$ before counting in the liquid scintillation counter. The efficiency of removal of unfixed ${ }^{14} \mathrm{C}$ was checked by adding known amounts of $\mathrm{Na}_{2}{ }^{14} \mathrm{CO}_{3}$ solution to acidified seawater samples and treating in the standard way: these control samples had counts which were not significantly different from background, indicating efficient removal of unfixed ${ }^{14} \mathrm{CO}_{2}$ by this procedure.

Photosynthetic pigments were measured in 2 ways Total population pigment was analysed by filtering samples through Whatman GF/F glass-fibre filters which were then frozen quickly and analysed on return to the laboratory. Pigment was extracted with $90 \%$ acetone and measured in a Pye Unicam SP8-100 recording spectrophotometer; the concentrations of chlorophyll and phaeopigments were calculated using 
the equations of Strickland \& Parsons (1972). Analysis of photosynthetic pigments in size-fractionated samples was carried out at sea as follows: $10 \mathrm{ml}$ water samples were filtered through $5 \mu \mathrm{m}, 1 \mu \mathrm{m}$ and $0.2 \mu \mathrm{m}$ Nuclepore filters, the filters were then extracted with ice-cold $90 \%$ actone for $3 \mathrm{~h}$ and the extracted pigment measured in a Turner fluorometer. Since acetone extracts a fluorescent compound from Nuclepore filters, a blank was prepared for each pore-size filter by extracting with $90 \%$ acetone and these blanks were used to zero the fluorometer.

Numbers of cyanobacteria were counted at sea in unpreserved water samples using a Leitz Ortholux II microscope with $50 \mathrm{~W}$ HBO light source and equipped with a Ploempak 2.2 fluorescence vertical illuminator, containing a BP 450-490 exciting filter, RKP 510 beamsplitting mirror and LP515 suppression filter (filter block $\mathrm{I}_{2}$ ) and an NPL Fluorotar 100/1.32 oil objective. The orange fluorescence of the phycoerythrin-containing cyanobacteria could be distinguished easily from the red fluorescence of the other phytoplankton. Other phytoplankton counts were made on sedimented subsamples, preserved with Lugol's iodine, which were examined using an inverted microscope (Hasle 1978).

\section{RESULTS}

\section{Primary production in summer 1983}

Our previous study in the summer of 1982 (Joint \& Pomroy 1983) demonstrated that picoplankton (i.e. cells passing through a $1 \mu \mathrm{m}$ pore-size Nuclepore filter) accounted for 20 to $30 \%$ and small nanoplankton $(<5$ to $1 \mu \mathrm{m}$ ) for 35 to $40 \%$ of the primary production. How representative were these data of summer phytoplankton production in the Celtic Sea? In June and August 1983, measurements were again made at Stn CS2. These measurements used a slightly different procedure: $0.8 \mu \mathrm{m}$ pore-size filters replaced the $1 \mu \mathrm{m}$ pore-size filters used in all other experiments and, in addition, $D \mathrm{O}^{14} \mathrm{C}$ production was not measured. If the incorporation of ${ }^{14} \mathrm{C}$ into phytoplankton biomass is compared and if the production of $\mathrm{DO}^{14} \mathrm{C}$ is ignored, the data obtained at the end of June 1983 were very similar to those in early July 1982. Only one in situ incubation was done in June 1983 and production in the 3 size fractions was $97 \mathrm{mg} \mathrm{C} \mathrm{m}^{-2} \mathrm{~d}^{-1}$ (>5 $\left.>\mathrm{m}\right)$, $164 \mathrm{mgC} \mathrm{m} \mathrm{m}^{-2} \mathrm{~d}^{-1}(<5$ to $>0.8 \mu \mathrm{m})$ and $61 \mathrm{mg} \mathrm{C} \mathrm{m}^{-2}$ $\mathrm{d}^{-1}$ for the picoplankton fraction $(<1 \mu \mathrm{m})$. These data compare with mean values of 3 in situ determinations done on 2 to 6 July 1982 of $76 \mathrm{mg} \mathrm{C} \mathrm{m}^{-2} \mathrm{~d}^{-1}(>5 \mu \mathrm{m})$, $153 \mathrm{mg} \mathrm{C} \mathrm{m}^{-2} \mathrm{~d}^{-1}(<5$ to $>1 \mu \mathrm{m})$ and $87 \mathrm{mg} \mathrm{C} \mathrm{m}^{-2} \mathrm{~d}^{-1}$ (<1 $\mu$ m fraction).

However, the data obtained in August 1983 were very different from those of the previous year. Again, only a single in situ determination was done at CS2 in August 1983 but production by phytoplankton cells $>5 \mu \mathrm{m}$ was much higher; the estimated depth-integrated production was $200 \mathrm{mgC} \mathrm{m}^{-2} \mathrm{~d}^{-1}$ (>5 $\left.\mu \mathrm{m}\right)$, $227 \mathrm{mgC} \mathrm{m} \mathrm{m}^{-2} \mathrm{~d}^{-1}(<5$ to $>0.8 \mu \mathrm{m})$ and $58 \mathrm{mg} \mathrm{C} \mathrm{m}^{-2}$ $\mathrm{d}^{-1}$ ( $<1 \mu \mathrm{m}$ fraction). These data compare with the means of 5 in situ measurements made between 19 and 26 August 1982 of $120 \mathrm{mg} \mathrm{C} \mathrm{m}^{-2} \mathrm{~d}^{-1}$ (>5 $\left.\mu \mathrm{m}\right), 230 \mathrm{mg}$ $\mathrm{C} \mathrm{m}^{-2} \mathrm{~d}^{-1}(<5$ to $>1 \mu \mathrm{m})$ and $190 \mathrm{mg} \mathrm{C} \mathrm{m}^{-2} \mathrm{~d}^{-1}$ $(<1 \mu \mathrm{m}$ fraction). The ratio of percentage production in the 3 size fractions $>5 \mu \mathrm{m}:<5$ to $>1 \mu \mathrm{m}:<1 \mu \mathrm{m}$ changed from 22.2:42.6:35.2 in August 1982 to 41.2: 46.8: 12 in August 1983.

Fig. 2 shows a typical production profile and vertical distribution of chlorophyll for August 1982, and comparable data for 26 August 1983. In both cases, a strong thermocline was present but the temperature of the surface mixed layer was much higher in 1983. The chlorophyll a concentration was also higher and was about 3 times the concentration present in August 1982. The production profile also shows large differences; in 1982 production by $<1 \mu \mathrm{m}$ and $<5$ to $>1 \mu \mathrm{m}$
Fig. 2. A comparison of profiles of temperature $(\cdots \cdots)$, chlorophyll $a(x)$ and size-fractionated primary production on 23 August 1982 and 26 August 1983 at Stn CS2; carbon fixation measured in 3 fractions, ( $\Delta)>5 \mu \mathrm{m}$, ( $)<5$ to $>1 \mu \mathrm{m}$, ( $<1 \mu \mathrm{m}$ phytoplankton (in August 1983, $0.8 \mu \mathrm{m}$ Nuclepore filters replaced the $1 \mu \mathrm{m}$ filters)
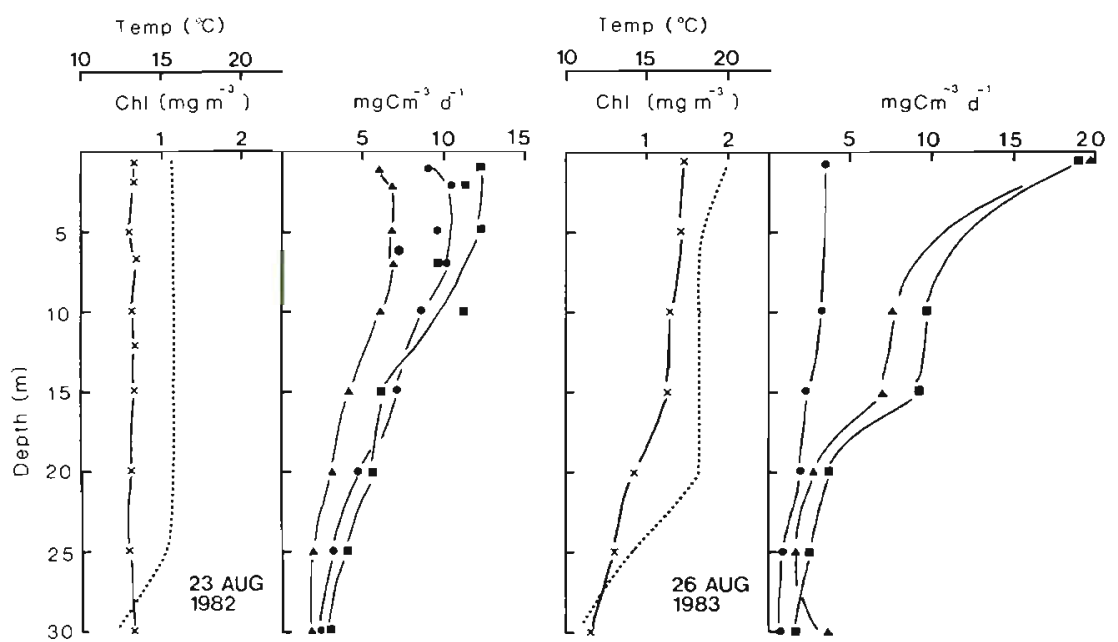
phytoplankton was comparable and showed similar depth profiles. However, in August 1983, production by $>5 \mu \mathrm{m}$ and $<5$ to $>1 \mu \mathrm{m}$ fractions was elevated in the surface $10 \mathrm{~m}$. Unfortunately, no estimations of production were obtained between the surface and 10 $m$ so we do not know how localised this production peak was to the sea surface. The increased chlorophyll $a$ concentrations and production by the $>5 \mu \mathrm{m}$ phytoplankton were the result of elevated numbers of Gymnodinium sp. and 2 unidentified flagellates which were all larger than $5 \mu \mathrm{m}$ diameter. The Gymnodinium sp. numbers were $1.7 \times 10^{4} 1^{-1}$ in the surface water in August 1982 but in 1983 the abundance was $8.3 \times 10^{4} 1^{-1}$. Cell numbers of the 2 flagellates were $11.2 \times 10^{4} \mathrm{l}^{-1}$ and $14.2 \times 10^{4} \mathrm{l}^{-1}$ in the surface $2 \mathrm{~m}$ in 1983 but were less than half those in the previous year.

\section{Primary production in winter}

Two measurements of primary production were made at Stn CS4 in December 1983. Chlorophyll was uniformally distributed in the upper $100 \mathrm{~m}$ at a concentration of between 0.25 and $0.4 \mathrm{mg} \mathrm{m}^{-3}$ but was less than $0.05 \mathrm{mg} \mathrm{m}^{-3}$ in water samples taken below $200 \mathrm{~m}$. Fig. 3 shows the vertical distribution of size-fractionated chlorophyll and primary production; the mean

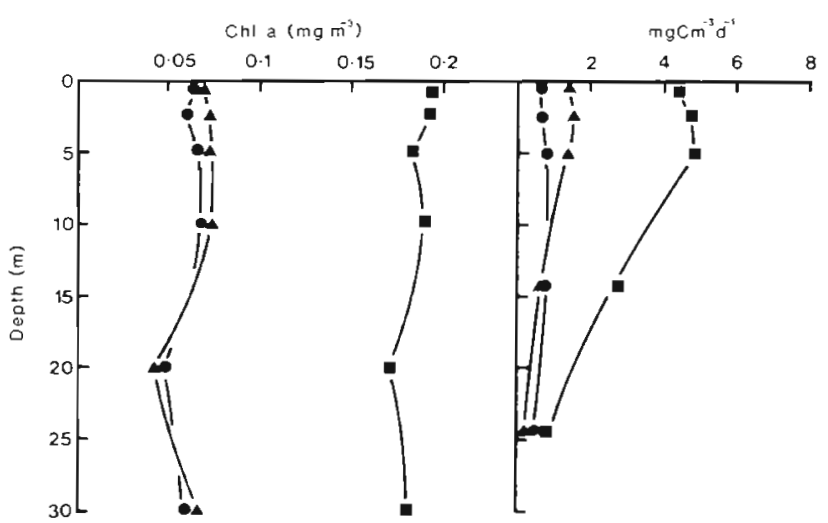

Fig. 3. Depth distribution of chlorophyll $a$ and carbon fixation in 3 size fractions, ( $\Delta)>5 \mu \mathrm{m},(\boldsymbol{\bullet})<5$ to $>1 \mu \mathrm{m},(\bullet)<1 \mu \mathrm{m}$ at Stn CS4 in Dec 1983

distribution of chlorophyll in the 3 size fractions was $18.1 \%$ (>5 $\mu \mathrm{m}), 63.0 \%(<5$ to $>1 \mu \mathrm{m})$ and $18.9 \%$ $(<1 \mu \mathrm{m})$. Depth-integrated production was calculated to be $19 \mathrm{mg} \mathrm{C} \mathrm{m}^{-2} \mathrm{~d}^{-1}$ for phytoplankton $>5 \mu \mathrm{m}, 67$ $\mathrm{mg} \mathrm{C} \mathrm{m}{ }^{-2} \mathrm{~d}^{-1}(<5$ to $>1 \mu \mathrm{m})$ and $13 \mathrm{mg} \mathrm{C} \mathrm{m}^{-2} \mathrm{~d}^{-1}$ for the picoplankton $<1 \mu \mathrm{m}$. The depth-integrated production in the different size fractions was $19.0 \%$ (>5 $\mu \mathrm{m}), 67.9 \%(<5$ to $>1 \mu \mathrm{m})$ and $13.1 \%(<1 \mu \mathrm{m})$ and was very similar to the distribution of chlorophyll in those fractions. Measurements made on 11 December 1983 gave almost identical results.

\section{Phytoplankton production in spring}

Sampling in April 1983 coincided with the beginning of the spring diatom bloom and $55 \%$ of the production was by phytoplankton $>5 \mu \mathrm{m}_{\text {; }}$ however, at the time of sampling, chlorophyll concentrations were below $2 \mathrm{mg} \mathrm{m}^{-3}$ and the bloom was just beginning. Nevertheless, mean picoplankton production for 2 in situ determinations was $80 \mathrm{mg} \mathrm{C} \mathrm{m} \mathrm{m}^{-2} \mathrm{~d}^{-1}$, that of $>5 \mu \mathrm{m}$ fraction was $244 \mathrm{mg} \mathrm{C} \mathrm{m} \mathrm{m}^{-2} \mathrm{~d}^{-1}$ and that of the $<5$ to $>1 \mu \mathrm{m}$ fraction was $154 \mathrm{mg} \mathrm{C} \mathrm{m} \mathrm{C}^{-2} \mathrm{~d}^{-1}$. Sampling in April of the following year took place during a welldeveloped diatom bloom. Fig. 4 shows the vertical

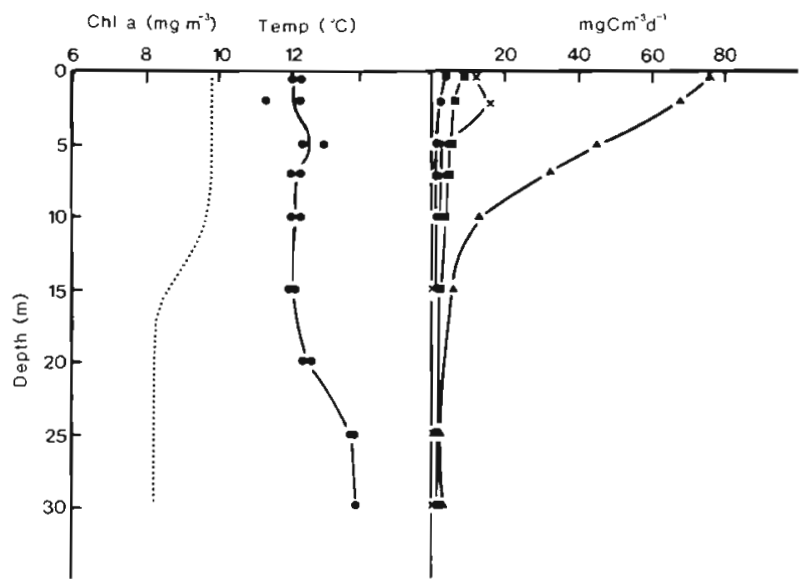

Fig. 4. Vertical profiles of temperature (․), chlorophyll a (- - and carbon fixation by phytoplankton at Stn M4 on 21 April 1984; (A) phytoplankton $>5 \mu \mathrm{m},(\mathbf{a})<5$ to $>1 \mu \mathrm{m}$, (•) $<1 \mu \mathrm{m},(x) \mathrm{DO}^{14} \mathrm{C}$

distribution of temperature and chlorophyll at Stn M4 on 21 April 1984. Chlorophyll a values were high $\left(12 \mathrm{mg} \mathrm{m}^{-3}\right)$ in the surface water but declined rapidly below $30 \mathrm{~m}$. Nitrate concentrations averaged $0.78 \mu \mathrm{mol}$ $1^{-1}$ and phosphate $0.28 \mu \mathrm{mol} 1^{-1}$ in the surface $25 \mathrm{~m}$. The production profile was clearly dominated by large phytoplankton (>5 $\mu \mathrm{m}) ; 90.7 \%$ of the chlorophyll $a$ at Stn M4 was retained by $5 \mu \mathrm{m}$ pore-size filters and $80 \%$ of the carbon fixed into the particulate fraction was by phytoplankton $>5 \mu \mathrm{m}$.

Microscopic examination showed the bloom to be dominated by 2 or 3 species of Thalassiosira and by numerous Hyalochaetes; there were ca $7.5 \times 10^{5} \mathrm{l}^{-1}$ Thalassiosira cells with dimensions of ca $20 \times 10 \mu \mathrm{m}$ and $2.7 \times 10^{5} 1^{-1}$ Hyalochaetes with cell diameters of $5 \mu \mathrm{m}$. These diatoms were largely responsible for the elevated levels of chlorophyll and the increased production by the $>5 \mu \mathrm{m}$ fraction. The mean number of cyanobacteria in the surface $30 \mathrm{~m}$ at Stn M4 on 20 April 1984 was $12.2 \times 10^{3}$ cells $\mathrm{ml}^{-1}$.

Carbon fixation by the different size fractions is shown in Table 1 for the different stations in the Celtic 
Table 1. Carbon fixation by different size fractions in the Celtic sea in April and May 1984. Depth-integrated primary production expressed as $\mathrm{mg} \mathrm{C} \mathrm{m}^{-2} \mathrm{~d}^{-1}$; values in parentheses are the percentage of total carbon fixed in each size fraction, excluding $D \mathrm{O}^{14} \mathrm{C}$

\begin{tabular}{|c|c|c|c|c|c|c|c|}
\hline \multirow[t]{2}{*}{ Size fraction } & \multicolumn{7}{|c|}{ Date [Station] } \\
\hline & $\begin{array}{c}20 \mathrm{Apr} \\
{[\mathrm{M} 4]}\end{array}$ & $\begin{array}{c}21 \mathrm{Apr} \\
{[\mathrm{B} 3]}\end{array}$ & $\begin{array}{c}24 \mathrm{Apr} \\
{[\mathrm{B} 4]}\end{array}$ & $\begin{array}{c}26 \mathrm{Apr} \\
{[\mathrm{B} 6]}\end{array}$ & $\begin{array}{c}20 \text { May } \\
\text { [M1] }\end{array}$ & $\begin{array}{l}29 \text { May } \\
\text { [M4] }\end{array}$ & $\begin{array}{c}30 \mathrm{May} \\
{[\mathrm{M} 4]}\end{array}$ \\
\hline$>5 \mu \mathrm{m}$ & $\begin{array}{c}534 \\
(80.2)\end{array}$ & $\begin{array}{c}595 \\
(74.8)\end{array}$ & $\begin{array}{c}784 \\
(83.1)\end{array}$ & $\begin{array}{c}545 \\
(75.9)\end{array}$ & $\begin{array}{c}161 \\
(57.7)\end{array}$ & $\begin{array}{c}199 \\
(32.7)\end{array}$ & $\begin{array}{c}96 \\
(25.2)\end{array}$ \\
\hline$<5$ to $>1 \mu \mathrm{m}$ & $\begin{array}{c}85 \\
(12.7)\end{array}$ & $\begin{array}{c}124 \\
(15.6)\end{array}$ & $\begin{array}{c}65 \\
(7.2)\end{array}$ & $\begin{array}{c}94 \\
(13.1)\end{array}$ & $\begin{array}{c}76 \\
(27.1)\end{array}$ & $\begin{array}{c}199 \\
(33.0)\end{array}$ & $\begin{array}{c}138 \\
(36.1)\end{array}$ \\
\hline$<1$ to $>0.2 \mu \mathrm{m}$ & $\begin{array}{c}48 \\
(7.1)\end{array}$ & $\begin{array}{c}77 \\
(9.6)\end{array}$ & $\begin{array}{c}92 \\
(9.7)\end{array}$ & $\begin{array}{c}79 \\
(11.0)\end{array}$ & $\begin{array}{c}42 \\
(15.2)\end{array}$ & $\begin{array}{c}206 \\
(34.2)\end{array}$ & $\begin{array}{c}148 \\
(38.7)\end{array}$ \\
\hline
\end{tabular}

Sea in April and May 1984. In April, DO ${ }^{14} \mathrm{C}$ production in the surface $5 \mathrm{~m}$ was greater than the amount of carbon fixed by both picoplankton and the $<5$ to $>1 \mu \mathrm{m}$ size fraction but in May $\mathrm{DO}^{14} \mathrm{C}$ production was about $10 \%$ of the ${ }^{14} \mathrm{C}$ in the particulate fraction. In April, production was dominated by large $(>5 \mu \mathrm{m})$ phytoplankton over the whole region. However, in May there were areas where production by picoplankton had increased significantly and equalled that of the $>5 \mu \mathrm{m}$ and the $<5$ to $>1 \mu \mathrm{m}$ fractions. Fig. 5 shows vertical profiles of production and chlorophyll for Stns M1 (on the shelf) and M4 (at the shelf break). At Stn M1 on 20 May 1984, chlorophyll a concentrations were greater than $1 \mathrm{mg} \mathrm{m}^{-3}$, with a chlorophyll maximum at $25 \mathrm{~m}$ depth, and $57.7 \%$ of the depth-integrated production was by phytoplankton $>5 \mu \mathrm{m}$. The chlorophyll peak at $25 \mathrm{~m}$ at Stn M1 was due to high concentrations of the diatom Cerataulina pelagica,

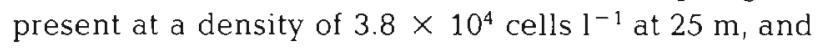
an unidentified flagellate, which was larger than $5 \mu \mathrm{m}$ and reached $7 \times 10^{4}$ cells $1^{-1}$. Carbon fixation by phytoplankton $>5 \mu \mathrm{m}$ was only slightly elevated in the chlorophyll maximum and there was no evidence of a production maximum at this depth. The production profile at Stn M4, at the shelf break, showed a complete contrast to that at Stn M1; production was almost equal in the 3 size fractions and chlorophyll a concentrations had declined to ca $0.6 \mathrm{mg} \mathrm{m}^{-3}$ (Fig. 5). However, although there was a consistent change in the proportion of production by the different size fractions, there did seem to be considerable variation in phytoplankton biomass and total production from day to day; the depth-integrated production by phytoplankton $>5 \mu \mathrm{m}$ on 29 May was double that on the following day and the chlorophyll a concentration in the surface $30 \mathrm{~m}$ averaged $0.37 \mathrm{mg} \mathrm{m}^{-3}$. Despite this phytoplankton distribution, the samples taken in May at these 2 stations on the shelf and at the shelf break do appear to typify the transition from the spring situation, where production is dominated by large phytoplankton, to the summer situation when small phytoplankton cells dominate.
Fig. 5. Vertical profiles of temperature $(\cdots \cdots)$, chlorophyll $a(\bullet \bullet)$, and carbon fixation by phytoplankton $>5 \mu \mathrm{m}(\mathbf{\Delta}),<5$ to $>1 \mu \mathrm{m}(\boldsymbol{\square})$ and $<1 \mu \mathrm{m}(\bullet)$ at Stns M1 and M4 in May 1984
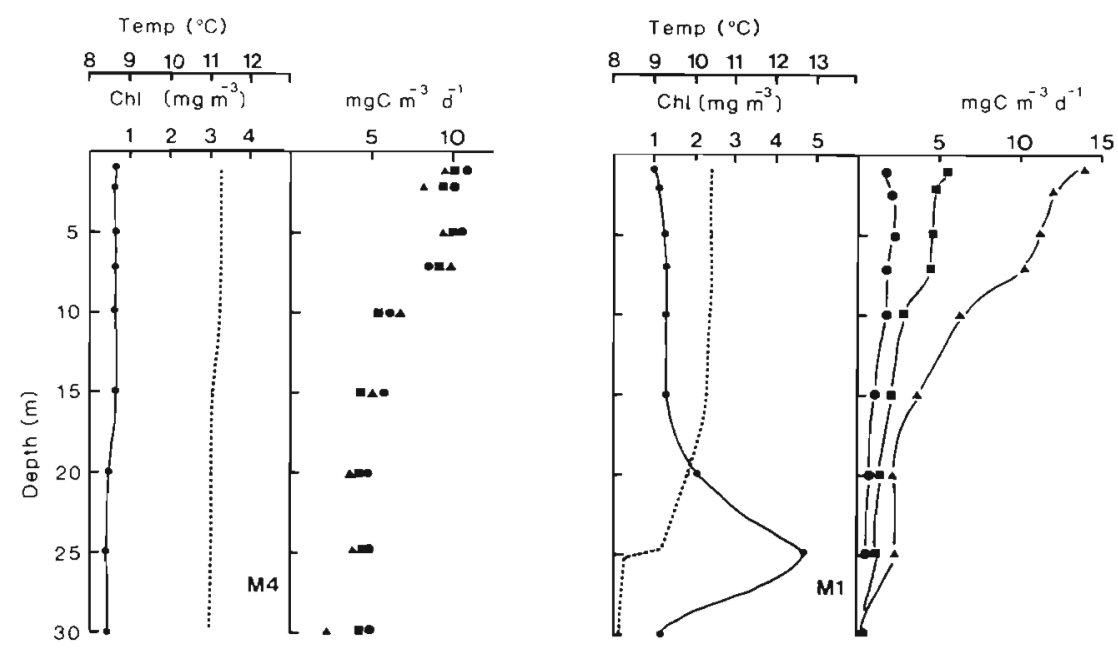


\section{Monthly production estimates for different size fractions}

The mean daily values and ranges of production estimates for the 3 size fractions of phytoplankton are shown in Fig. 6 for each month in which measurements were made. Highest values of production were measured in April 1984 at the time of the diatom spring

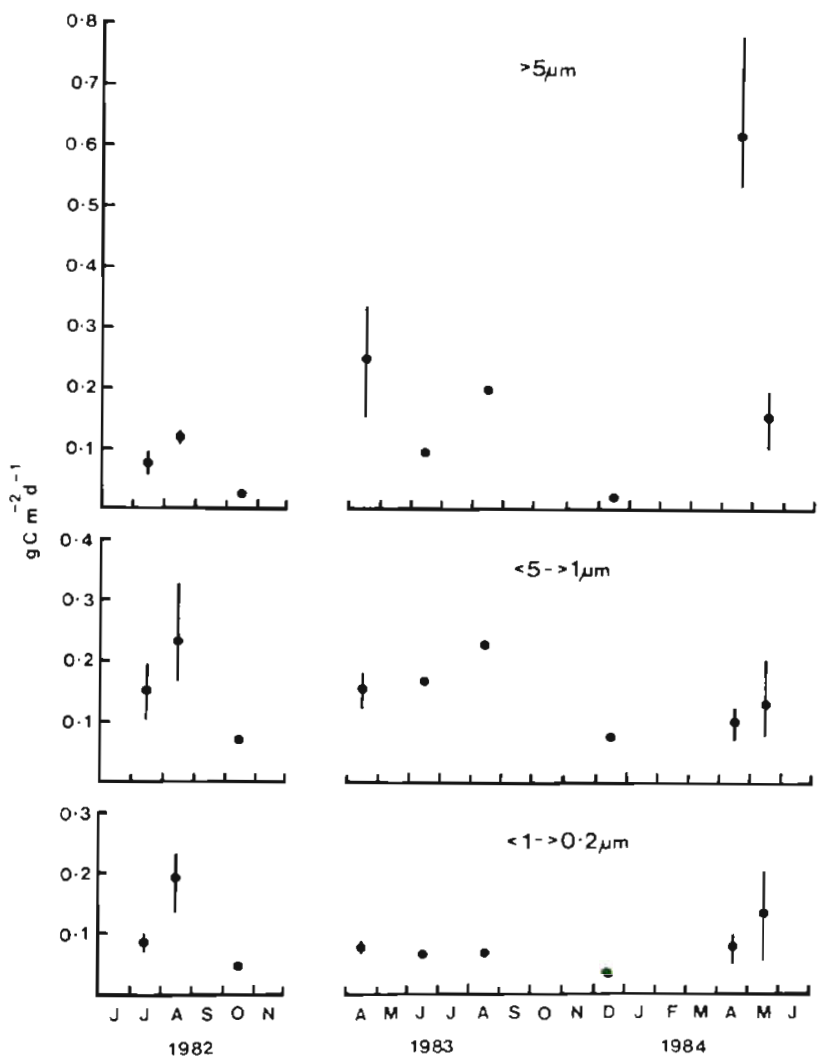

Fig. 6. Estimates of depth-integrated primary production in the Celtic Sea. A total of 22 day-length, in situ incubations were done between Jul 1982 and May 1984. Mean values; bars show ranges obtained on each cruise. There was only 1 measurement each month in Oct 1982, Jun and Aug 1983; in Dec 1983, the range of determinations was smaller than the symbol. For all measurements in Apr, Jun and Aug 1983, a 0.8 $\mu \mathrm{m}$ pore-size Nuclepore filter was used in place of $1 \mu \mathrm{m}$ filters

bloom; the measurements in April 1983 were lower because the sampling period did not coincide with the peak in the spring bloom. Production by phytoplankton cells $<5$ to $>1$ um showed very little variation from year to year but there was some variation in picoplankton production.

\section{DISCUSSION}

The data presented in this paper have extended our measurements of picoplankton production in the Celtic Sea to every season. The data obtained in early sum- mer 1983 agreed well with that in 1982 (Joint \& Pomroy 1983). However, in late summer there was much more variability between years. Carbon fixation by picoplankton was much lower in August 1983 than in 1982. This may be partly a result of the use of $0.8 \mu \mathrm{m}$ sieves in place of the usual $1 \mu \mathrm{m}$ pore-size filters; these smaller pores would probably have retained all the eukaryotic picoplankton, the smallest of which Joint \& Pipe (1984) found to be $0.85 \mu \mathrm{m}$ diameter, as well as some of the larger cyanobacteria. In contrast to 1982, there were long periods of sunshine during August 1983 and it appears that the development of the larger phytoplankton cells was favoured. However, this development was not uniform over the whole of the Celtic Sea measurements made at the shelf break (Stn GL7) on the same cruise gave results which were much more similar to the data obtained at CS2 in the previous year. At GL 7, 22 to $24 \%$ of the production occurred in both the $>5 \mu \mathrm{m}$ and the $<1 \mu \mathrm{m}$ fractions and $55 \%$ was by cells $<5$ to $>1 \mu \mathrm{m}$. We have no information on the size of the patches or the distribution of the elevated numbers of larger ( $>5 \mu \mathrm{m}$ ) phytoplankton in the Celtic Sea.

The measurements of primary production made in December 1983 are the only data we have for the Celtic Sea in winter but we believe that the rates measured are typical of winter conditions; samples had been taken in January 1983, at Stn CS2, for chlorophyll and phytoplankton analysis. Although weather conditions did not allow any experimental work, those analyses did show strong similarity with the data obtained in the following December. Chlorophyll a concentrations were almost identical on the 2 occasions and phytoplankton analysis showed very similar species composition. Phytoplankton biomass in January 1983 was dominated by small flagellates and the biomass of these flagellates was only $10 \%$ less than that found in December 1983. These findings are consistent with the data of Hannah \& Boney (1983) who found that nanoplankton was responsible for all of the carbon fixation in the Firth of Clyde, Scotland in winter Since numbers of phytoplankton and chlorophyll a concentrations were so similar in 2 winters at 2 different stations in the Celtic Sea, it seems reasonable to accept that the rates of primary production measured in December 1983 are typical of winter values for the region. The data obtained in spring 1983 and 1984 show that this is the only time of year when large phytoplankton (>5 $\mu \mathrm{m}$ ) is responsible for most of the carbon fixation. The spring diatom bloom is relatively short-lived and is largely restricted to $1 \mathrm{mo}$.

For the purposes of investigating the interactions of phytoplankton within the pelagic ecosystem, it is of interest to estimate the approximate annual production; Fig. 7 shows the estimated monthly primary production by the 3 size fractions of phytoplankton. The 

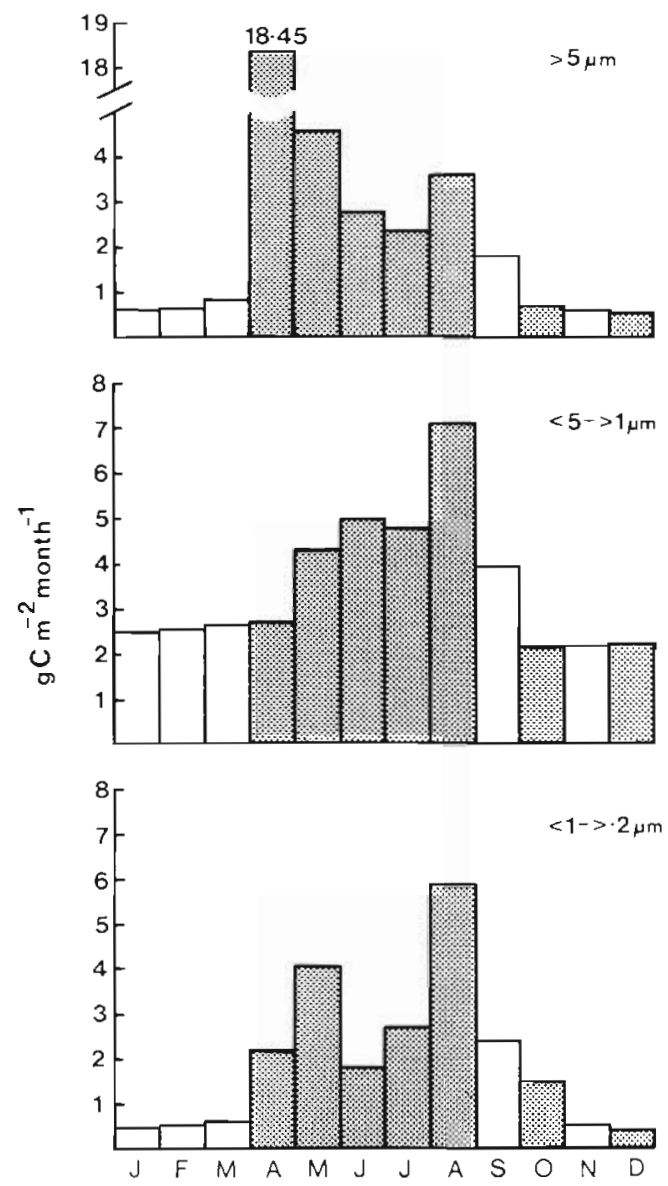

Fig. 7 Estimated monthly primary production rates for the Celtic Sea. Shaded parts of figure indicate months when measurements were made; other values estimated as described in the text

mean of the measured production rates in any 1 mo (from Fig. 6) have been assumed to be typical for that month, and this rate has been assumed to be constant for the whole of the calender month. The daily rates for September and November have been obtained by interpolating between adjacent months; estimates from January to March are based on the values obtained in December adjusted to allow for increasing day length. Total estimated primary production (excluding dissolved organic carbon exudation, which was between 10 and $15 \%$ of total carbon fixation) was $102.81 \mathrm{~g} \mathrm{C} \mathrm{m}^{-2} \mathrm{yr}^{-1}$; phytoplankton $>5 \mu \mathrm{m}$ fixed 37.89 $\mathrm{g} \mathrm{C} \mathrm{m}^{-2} \mathrm{yr}^{-1}$, cells $<5$ to $>1 \mu \mathrm{m}$ fixed $41.86 \mathrm{~g} \mathrm{C} \mathrm{m}^{-2}$ $\mathrm{yr}^{-1}$ and picoplankton fixed $23.06 \mathrm{~g} \mathrm{C} \mathrm{m}^{-2} \mathrm{yr}^{-1}$. Picoplankton was responsible for $22.4 \%$, cells $<5$ to $>1$ $\mu \mathrm{m}$ for $40.7 \%$ and phytoplankton $>5 \mu \mathrm{m}$ for $36.8 \%$ of the primary production. These estimates were obtained using the data obtained in August 1982; if the data of August 1983 are substituted, when increased number of large phytoplankton species were present at CS2, then the estimated annual production is $101.20 \mathrm{~g}$
$\mathrm{C} \mathrm{m}^{-2} \mathrm{yr}^{-1}$ and the percentage contribution of picoplankton falls to $18.8 \%$, that of $>5 \mu \mathrm{m}$ cells increases to $39.9 \%$ and the contribution by phytoplankton $<5$ to $>1 \mu \mathrm{m}$ remains the same at $41.3 \%$.

Apart from the significant contribution that small phytoplankton makes to primary production in the Celtic Sea, the most notable feature of our data is the marked seasonality in the production by large (>5 $\mu \mathrm{m})$ phytoplankton. Although these cells account for about $40 \%$ of the annual primary production, half of this production occurs in $1 \mathrm{mo}$, April. These findings have implications for our understanding of the functioning of the pelagic ecosystem in temperate shelf seas. Crustaceous zooplankton does not appear to graze efficiently on particles smaller than 3 to $4 \mu \mathrm{m}$ (Boyd 1976, Conover 1978, Capriulo \& Ninivaggi 1982, Johnson et al. 1982) yet copepods and euphausiids make up the major zooplankton biomass in the Celtic Sea. In August 1982, 2 species of Calanus and 2 species of euphausiid accounted for 90 to $95 \%$ of the zooplankton captured by $280 \mu \mathrm{m}$ mesh net (Joint \& Williams 1985) and had a total biomass of 2.1 to $2.8 \mathrm{~g} \mathrm{C} \mathrm{m}^{-2}(0$ to 100 $\mathrm{m})$. Therefore, if this zooplankton can only graze on phytoplankton cells that are larger than $5 \mu \mathrm{m}$, then only $37 \%$ of the annual primary production can be directly available to the major herbivores; furthermore, half of the production by phytoplankton $>5 \mu \mathrm{m}$ (18.45 $\mathrm{g} \mathrm{C} \mathrm{m}^{-2} \mathrm{mo}^{-1}$ ) occurred in April. Colebrook (1979) showed from Continuous Plankton Recorder surveys that the biomass of zooplankton in the region did not reach a maximum until May; therefore, half of the production of large phytoplankton occurred before the maximum development of a population of grazers which could exploit this phytoplankton population. Joint \& Williams (1985) calculated that there was insufficient primary production by phytoplankton $>5 \mu \mathrm{m}$ in August 1982 to meet the demands of the copepod and euphausiid populations that were present. However, if these animals were able to graze on phytoplankton cells $<5$ to $>1 \mu \mathrm{m}$, then this zooplankton population could be sustained by the measured primary production.

The fate of picoplankton and small nanoplankton is unknown; the recent hypotheses of Azam et al. (1983) on the functioning of the microbial food web suggest that protozoan microflagellates are important in grazing bacteria and presumably also picoplankton. However, Joint \& Williams (1985) calculated that there were insufficient heterotrophic microflagellates present in August 1982 to make a significant grazing impact on picoplankton but the production of the heterotrophic microflagellates probably balanced the production of the heterotrophic bacteria. The inclusion of another trophic level in the pelagic food web also has obvious implications for the efficiency with which 
energy is transferred from phytoplankton to macrozooplankton and fish. The fate of picophytoplankton production is still not known and the rate at which picoplankton and small nanoplankton production is incorporated into the food web requires quantification.

Acknowledgements. This work forms part of the continental shelf research programme of the Institute for Marine Environmental Research, a component of the U.K. Natural Environment Research Council.

\section{LITERATURE CITED}

Azam, F., Fenchel, I., Field, J. C., Gray, J. S., Meyer-Reil, L. A., Thingstad, F. (1983). The ecological role of watercolumn microbes in the sea. Mar. Ecol. Prog. Ser. 10: $257-263$

Bienfang, P. K., Szyper, J. P., Okamoto, M. Y., Noda, E. K. (1984). Temporal and spatial variability of phytoplankton in a subtropical ecosystem. Limnol. Oceanogr. 29: $527-539$

Boyd, C. M. (1976). Selection of particle sizes by filter-feeding copepods: a plea for reason. Limnol. Oceanogr. 21: 175-180

Capriulo, G. M., Ninivaggi, D. V (1982). A comparison of the feeding activities of field collected tintinnids and copepods fed identical natural particle assemblages. Annls Inst. océanogr., Paris 58: 325-334

Colebrook, J. M. (1979). Continuous plankton records: seasonal cycles of phytoplankton and copepods in the North Atlantic Ocean and North Sea. Mar Biol. 51: 23-32

Conover, R. J. (1978). Feeding interactions in the pelagic zone. Rapp. P.-v. Réun. Cons. int. Explor. Mer 173: 66-76

Douglas, D. J. (1984). Microautoradiography-based enumeration of photosynthetic picoplankton with estimates of carbon-specific growth rates. Mar. Ecol. Prog. Ser 14: 223-228

Gieskes, W. W. C., Kraay, G. W., Baars, M. A. (1979). Current ${ }^{14} \mathrm{C}$ methods for measuring primary production: gross underestimation in oceanic waters. Neth. J. Sea Res. 13: $58-78$

Hannah, F. J., Boney, A. D. (1983). Nanoplankton in the Firth of Clyde, Scotland: seasonal abundance, carbon fixation and species composition. J. exp. mar Biol. Ecol. 67: 105-147

Hasle, G. R. (1978). Using the inverted microscope. In: Sournia, A. (ed.) Phytoplankton manual. UNESCO, Paris, p. 191-196

Johnson, P. W., Sieburth, J. McN. (1979). Chroococcoid cyanobacteria in the sea: a ubiquitous and diverse phototrophic biomass. Limnol. Oceanogr 24: 928-935

Johnson, P. W., Sieburth, J. McN. (1982). In situ morphology and occurrence of eucaryotic phototrophs of bacterial size in the picoplankton of estuarine and oceanic waters. J Phycol. 18: 318-327

Johnson, P. W., Xu, H.-S., Sieburth, J. McN. (1982). The utilization of chroococcoid cyanobacteria by marine protozooplankters but not by calanoid copepods. Annls Inst. océanogr., Paris 58: 297-308

Joint, I. R., Pomroy, A. J. (1983). Production of picoplankton and small nanoplankton in the Celtic Sea. Mar Biol. 77 $19-27$

Joint, I. R., Pipe, R. K. (1984). An electron microscope study of a natural population of picoplankton from the Celtic Sea. Mar. Ecol. Prog. Ser. 20: 113-118

Joint, I. R., Williams, R. (1985). Demands of the herbivore community on phytoplankton production in the Celtic Sea in August. Mar Biol. 87: 297-306

Krempin, D. W., Sullivan, C. W. (1981). The seasonal abundance, vertical distribution and relative biomass of chroococcoid cyanobacteria at a station in southern California coastal waters. Can. J. Microbiol. 27 $1341-1344$

Li, W K. W., Subba Rao, D. V., Harrison, W. G., Smith, J. C., Cullen, J. J., Irwin, B., Platt, T. (1983). Autotrophic picoplankton in the tropical ocean. Science, N. Y. 219: 292-295

Murphy, L. S., Haugen, E. M. (1985). The distribution and abundance of phototrophic ultraplankton in the North Atlantic. Limnol. Oceanogr. 30: 47-58

Platt, T., Subba Rá, D. V., Irwin, B. (1983). Photosynthesis of picoplankton in the oligotrophic ocean. Nature, Lond. 301 $702-704$

Sieburth, J. McN., Smetacek, V., Lenz, J. (1978). Pelagic ecosystem structure: heterotrophic compartments of the plankton and their relationship to plankton size. Limnol. Oceanogr 23: 1256-1263

Smith, J. C., Platt, T., Li, W. K. W., Horne, E. P. W., Harrison W. G., Subba Rao, D. V., Irwin, B. D. (1985). Arctic marine photoautotrophic picoplankton. Mar Ecol. Prog. Ser. 20 $207-220$

Strickland, J. D. H., Parsons, T. R. (1972). A practical handbook of seawater analysis, 2 nd ed. Bull. Fish. Res. Bd Can. 167

Takahashi, M., Bienfang, P. K. (1983). Size structure of phytoplankton biomass and photosynthesis in subtropical Hawaiian waters. Mar. Biol. 76: 203-211

Takahashi, M., Hori, T (1984). Abundance of picoplankton in the subsurface chlorophyll maximum layer in subtropical and tropical waters. Mar. Biol. 79: 177-186

Waterbury, J. B., Watson, S. W., Guillard, R. R. L., Brand, L. E. (1979). Widespread occurrence of a unicellular, marine, planktonic cyanobacterium. Nature, Lond. 277: 293-294

Wessels, C., Birnbaum, E. (1979). An improved apparatus for use with the ${ }^{14} \mathrm{C}$ acid-bubbling method of measuring primary production. Limnol. Oceanogr 24:187-188

Wiebe, W. J., Smith, D. F. (1977). ${ }^{14} \mathrm{C}$ labelling of the compounds excreted by phytoplankton for employment as realistic tracer in secondary productivity measurements. Microb. Ecol. 4: 1-8 